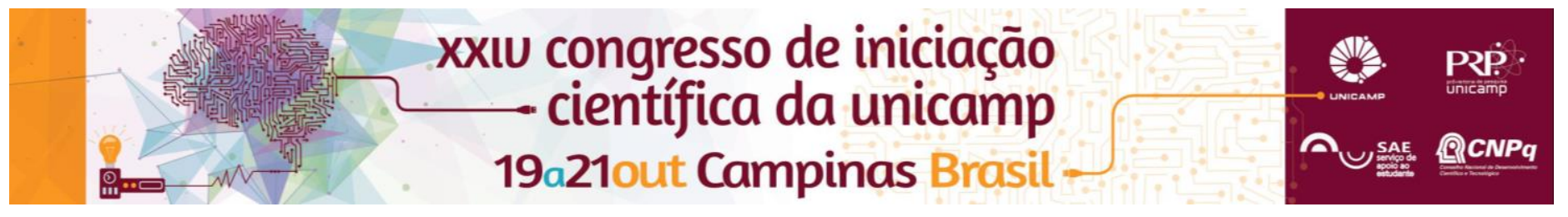

\title{
Projeto lei n608/2013: política e burocracia na violência policial
}

\author{
Rodrigo C. Lopes*, Frederico N.R. Almeida.
}

\section{Resumo}

O objetivo da pesquisa é compreender as possibilidades de controle político sobre a atividade policial no Brasil, a partir do estudo de iniciativas legislativa e judicial que tentaram proibir o uso de balas de borracha pela Polícia Militar de São Paulo, após a repressão às manifestações de junho de 2013: um Projeto de Lei que tramitou na Assembleia Legislativa do Estado de São Paulo, e uma Ação Civil Pública da Defensoria Pública do estado que pedia ao Poder Judiciário fiscalização e multa ao Executivo estadual por casos de violência policial em protestos, incluindo o uso das balas de borracha. Os processos legislativo e judicial caminharam paralelamente, fazendo emergir disputas semelhantes a respeito do controle da atividade policial e dos modelos de segurança pública que nos permeiam; além disso, colocaram no jogo político o Poder Judiciário, para além do conflito entre parlamento e burocracia.

Palavras-chave: Política e Burocracia, segurança pública, mobilização do direito. .

\section{Introdução}

A partir da análise de conteúdo dos processos legislativo e judiciário que debatem a questão do uso de elastômetro pela Polícia Militar, o objetivo desta pesquisa foi o de verificar as possibilidades institucionais de controle da atividade policial, bem como buscar os modelos de segurança em pauta nos argumentos em disputa. Além disso, trabalhou-se a especificidade do papel do poder Judiciário dentro do jogo político democrático abordado.

Analisou-se os seguintes documentos do processo legislativo: o Projeto de Lei 608/2013 que coíbe o uso de bala de borracha (elastômetro), o pedido de urgência para que o projeto fosse votado, e o veto total à lei pelo governador do estado. No processo judicial, as análises se deram a partir dos seguintes documentos: a peça inicial da Ação Civil Pública elaborada pela Defensoria Pública, a decisão liminar concedida pelo juiz de primeira instância, o recurso e 0 agravo de instrumento do Executivo, bem como a decisão de segunda instância que cassou a liminar.

\section{Resultados e Discussão}

O problema acerca da segurança e do controle da polícia militar se dá em dois aspectos institucionais: 1) O debate sobre a segurança durante a constituinte de 1988 não alterou substancialmente os fundamentos da ditadura militar de "segurança nacional". Sendo assim, pouco se mudou na maneira de se solucionar e mediar conflitos $^{1}$. A consequência disso seria um modelo de segurança que ainda trabalha na procura de um inimigo interno, ao invés de visar a proteção de seus cidadãos. Ou seja, um sistema que trabalha a partir da desconfiança na relação policial-cidadão. 2) O sistema político brasileiro, faz com que as instituições se sobrepusessem umas às outras, criando uma hierarquia entre elas e burocratizando suas relações. As normas institucionais, desse modo, centralizam o poder de decisão sempre nas mãos de apenas um órgão ou indivíduo. ${ }^{2}$

O foco da análise se deu no tempo dos processos judiciário e legislativo em comparação ao contexto político estadual, os argumentos contidos nos documentos e o uso do vocabulário jurídico para legitimar fins políticos. Válido ressaltar que tanto no Legislativo como no Judiciário, a decisão final foi em prol da não proibição do uso do elastômetro. Percebeu-se que as datas importantes para 0 andamento dos processos se encontram com as movimentações políticas das ruas durantes os protestos da copa das confederações e copa do mundo.

\section{Conclusões}

A literatura sobre o controle da Polícia Militar discute se seu problema se dá nas heranças da ditadura civil-militar dentro da gestão de políticas públicas ou se na centralidade que alguns órgãos detêm na hora da decisão final. No processo analisado, percebeu-se que os dois problemas permeiam os documentos analisados, ou seja. Além disso, as argumentações presentes nos dois documentos de decisão final (veto do Executivo e a cassação da liminar pelo Tribunal de Justiça) reforçam o argumento de que não cabem interferências externas (seja do Legislativo, seja do Judiciário) sobre o conteúdo específico das atividades policiais, que seriam definidos a partir de considerações de ordem técnica, segundo os documentos. Nesse aspecto, os argumentos ao final predominantes reproduzem uma mesma concepção de atividade policial e de segurança pública resistente aos avanços democráticos.

\section{Agradecimentos}

Agradeço ao CNPQ e à Universidade Estadual de Campinas pela oportunidade de pesquisa; Ao meu orientador Frederico Almeida pelo seu auxílio e compreensão durante todo o processo. Bem como, aos meus amigos, minha mãe e minha namorada Ana que me apoiaram durante $o$ ano conturbado que foi $o$ da pesquisa.

\footnotetext{
${ }^{1}$ Lima, Renato Sérgio de. Segurança Pública e os 20 anos da constituição cidadã: São Paulo: Alameda, 2011.

2 ESPÍRITO SANTO, Lúcio Emílio do (Coaut.de); MEIRELES, Amauri. Entendendo a nossa insegurança. Belo Horizonte: Instituto Brasileiro de Policiologia: Instituto Brasileiro de Segurança e Trânsito, 2003. 424 p., il. Inclui bibliografia. ISBN (broch) e WEBER, Max. Parlamentarismo e governo numa Alemanha reconstruída. In: Max Weber - Textos selecionados. São Paulo: Abril Cultural, 1980.
} 